\title{
Groundwater Quality Patterns and Spatiotemporal Change in Depletion in the Regions of the Arabian Shield and Arabian Shelf
}

\author{
Othman Abdurrahman Fallatah ${ }^{1}$
}

Received: 3 December 2018 / Accepted: 26 July 2019 / Published online: 11 October 2019

(c) The Author(s) 2019

\begin{abstract}
Groundwater quality is a critical issue in arid and semiarid countries, where it is one of the most reliable sources of water on which people depend. Water quality is a vital concern in the Kingdom of Saudi Arabia as it affects the health of its people, the growth of its agriculture, and its economic development. In this study, the objectives were to: (1) investigate the depletion rate of groundwater storage (GWS) in the study area by using Gravity Recovery and Climate Experiment (GRACE) data from April 2002 to April 2016 to quantify terrestrial water storage; (2) determine the ionic composition of cations and anions for 24 samples (12 samples from Arabian Shield and 12 from Arabian Shelf in Saudi Arabia); and (3) assess the water quality of the aquifer. The results show a GRACE-derived GWS depletion of $-2 \pm 0.13 \mathrm{~km}^{3} /$ year. Ionic compositions reveal two main groups: group I, with well depths of 144-607 m, and group II, with well depths of 12-150 m. Group I waters (all from the Saq aquifer) appear to be fossil waters, while group II waters (alluvial aquifer) appear to be mixed waters. As illustrated by the use of a Piper diagram, $85 \%$ of the samples in Arabian Shelf are characterized as a mixed water of calcium, magnesium, chloride, and sulfate $\left(\mathrm{SO}_{4}\right)$. In the Arabian Shield, $50 \%$ of the samples are characterized as $\mathrm{Ca}-\mathrm{Cl}$ waters. Since most of the samples (98\%) are from domestic wells used for drinking water and have the potential for radioactivity in the groundwater, it is essential to complete radioactive analysis and confirm acceptable water quality, based on the standards of the Water Health Organization and the Saudi Arabian Standards Organization.
\end{abstract}

Keywords Groundwater quality · Groundwater depletion · Arabian Shield · Arabian Shelf · GRACE · Hydrochemical · Cations · Anions

\section{Introduction}

Freshwater resources in the Kingdom of Saudi Arabia (KSA) are extremely vulnerable to both climate change and human interventions $[1,2]$. During the dry and wet seasons, the recharge rates of the underlying aquifer systems vary significantly; groundwater levels increase in the wet climatic period and fall in the dry period [3]. There are several reasons for human intervention in a given hydrologic system. The construction of dams (reservoirs) allows expanded use and utilization of a surface water resource. A lack of development programs for the evaluation of alternative renewable water resources leaves communities with no practical alternative. The management and development of these resources

Othman Abdurrahman Fallatah

ofallatah@kau.edu.sa

1 Faculty of Engineering, Radiation Protection and Training Centre, King Abdulaziz University, P.O. Box 80204, Jeddah 21589, Saudi Arabia are important for sustaining population growth and growing the country's agricultural, industrial, and tourism sectors. The population of the KSA is on the rise: in 1960: $4 \times 10^{6}$; in 2010: $27.3 \times 10^{6}$; by 2050 , an estimated: $59.5 \times 10^{6}$ [4]. Its annual consumption of freshwater resources is rising as well: in $2010,17.9 \times 10^{9} \mathrm{~m}^{3}$; by 2050 , an estimated: $19.5 \times 10^{9}$ $\mathrm{m}^{3}$ [5]. The study area was chosen to investigate the differences in water quality from different geological formation in the inland regions of northern Arabian Peninsula. This study also gives an extraordinary chance to look at the effects of climatic and anthropogenic forcing on a land-locked hydrological system. Although the groundwater system is a critical supply of water in this water-scarce region, its current usage is not sustainable; over-exploitation of the groundwater and the potential deterioration in its quality represent major threats to its long-term viability. The population of the study areas in 2010 was 571,717 persons within the Arabian Shelf and 224,708 persons within the Arabian Shield [4]. 
Understanding the natural phenomena (e.g., rainfall/temperature patterns, duration, and magnitude) together with human-related factors (e.g., population growth, overexploitation, and pollution) is important to maintain the livelihood of the human population in a sustainable manner. Despite the significance of the Saq aquifer system in the KSA, there are major difficulties associated with managing the groundwater system. The most critical of these difficulties is the unsustainable over-exploitation of the aquifer, which also significantly influences the water quality. Demand for water in Saudi Arabia increased from 2352 million cubic meters (MCM) in 1980 to more than 20,000 MCM in 2004 [6]. Of this, $88 \%$ is for irrigated agriculture, $9 \%$ for domestic use, and 3\% for industrial needs. Potential and development of the Saq aquifer have been studied by different researchers [7-15]. In addition, several studies focused on water quality [16-21]. This area needs more research to sustain the Saq aquifer as the main water supply.

The present study focuses on the water quality of groundwater samples from the Arabian Shield and Arabian Shelf and how the depletion rate affects it. It also examines their suitability for drinking water and domestic purposes, by comparing it to World Health Organization (WHO) global standards and Saudi Arabian Standards Organization (SASO) standards for bottled and unbottled drinking water [22]. It is worth mentioning that this study (1) investigates the depletion rate of groundwater storage (GWS) in the study area by using Gravity Recovery and Climate Experiment (GRACE) data (from April 2002 to April 2016) to quantify terrestrial water storage (TWS); (2) determines the ionic composition of cations and anions for 24 samples (12 samples from Arabian Shield and 12 from Arabian Shelf in Saudi Arabia); and (3) assesses the water quality of the aquifer.

\section{Study Area}

\subsection{Arabian Shield}

The Arabian Shield occupies the west-central one-third of the KSA and is part of the larger Afro-Arabian Shield [7, 23]. It is the geologic base of the central Najd, Hejaz, and Asir regions and extends from 50 to $700 \mathrm{~km}$ inland from the Red Sea toward Riyadh. This ancient landmass consists of igneous and metamorphic rocks of Precambrian Era (the oldest of them about 1170 million years old [7]) (Fig. 1). Basalts of mid-Tertiary and Quaternary Periods, 26 million years old or younger, are spread over western parts of the Shield and form the harrat $[7,24]$. Sedimentary rocks of the Paleozoic
Era, between 570 million and 225 million years old, and modern alluvium partly overlie the Shield itself. A narrow strip of Tertiary to Quaternary Period sedimentary rocks, including alluvium and related surficial deposits, also mantles the Precambrian Era rocks between the base of the mountain and the Red Sea coast, where the structural relationships are complicated by faults connected with the Red Sea rift [25]. For the most part, shield rocks are relatively impermeable and are therefore are not significant aquifers [26]. Locally, however, small yields of water might be found in the heavily jointed or fractured crystalline rock of the shield or in the younger basalt. The Shield influences the water resources in other ways; it forms the highest parts of the Kingdom and substantially controls the drainage and distribution of rainfall, which runs off through the wadis and is then available to recharge the groundwater. Because the rocks of the Shield are commonly impermeable, they shed most of the rain that falls on them, shunting relatively large percentages of the rainfall to the adjacent bodies of sedimentary rocks, which can take in and store some of the water [13].

\subsection{Arabian Shelf}

When the vast mass of crystalline rocks that form the eastward extension of the Shield was slowly and progressively tilted downward to the northeast by tectonic activity, a shallow sea occupied the eastern part of the Arabian Peninsula and received layer after layer of sedimentary deposits [13]. The deposition of these sediments began during the Cambrian Period (more than 500 million years ago) and continued, with several interruptions, until about the Pliocene Epoch, which ended 2.6 million years ago [13]. Subsequent geologic events resulted in the folding and emergence of this part of the peninsula. Erosion by wind and water has since sculpted the land into its present form as the Arabian Shelf (Fig. 1). The character of the sedimentary rocks (mainly limestone, sandstone, and shale) is known from data accumulated over many years from geologic and geophysical surveys, test holes, and production wells for the extraction of petroleum or water. The sedimentary units have an aggregate thickness as high as $5500 \mathrm{~m}$, thinning toward the west as the basement rocks become shallower. The critical water-controlling role of the geology is underscored by how these sedimentary rocks hold virtually all the naturally occurring freshwater that is available in the kingdom [26]. Some of the sedimentary rock layers, mainly sandstone and limestone, have considerable interconnected pore space or other openings that are filled with freshwater and can conduct water readily to wells [7, 23, 24, 26-28]. 
Fig. 1 Geological map for Arabian Shield and Arabian Shelf

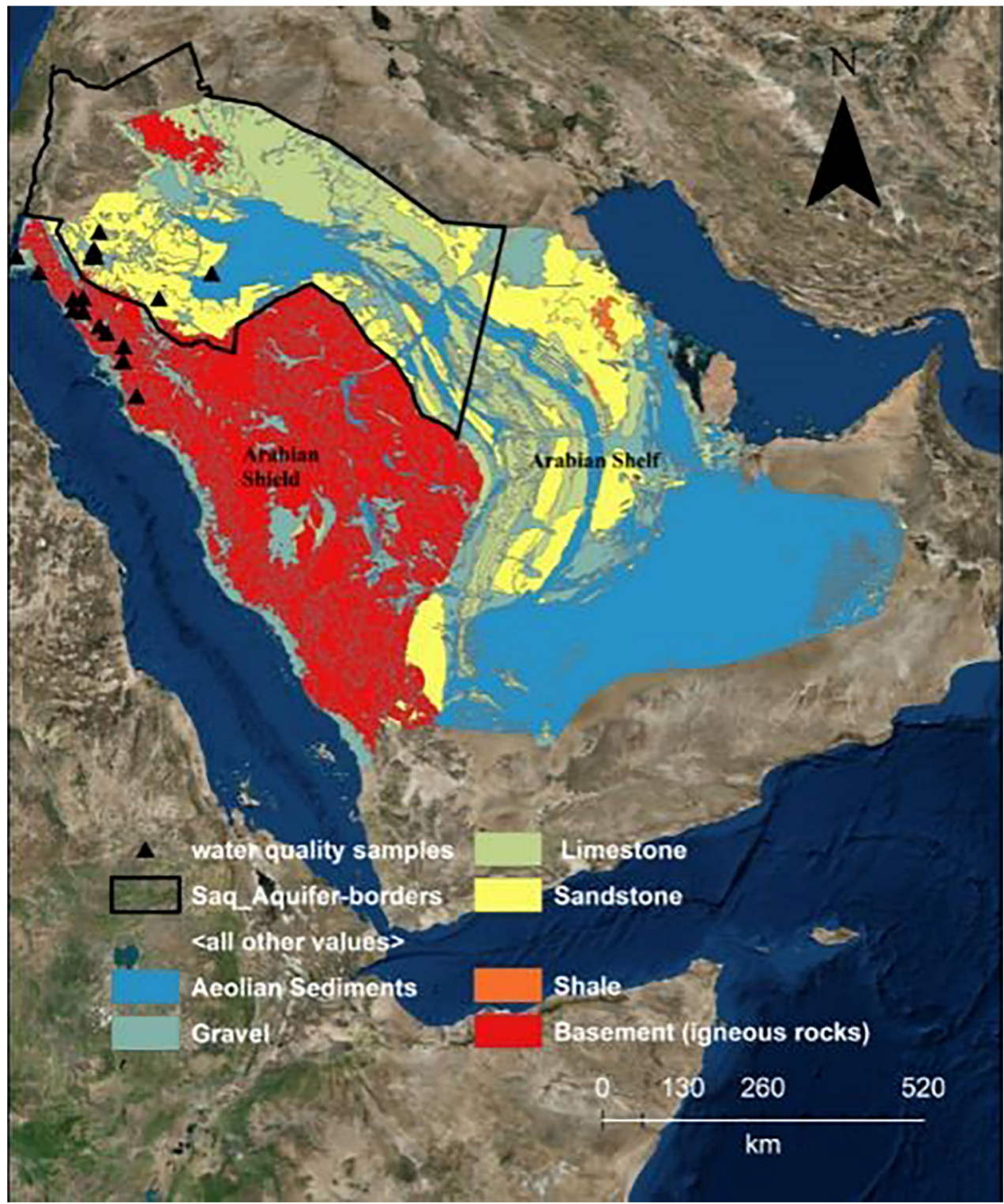

\section{Data and Methods}

\subsection{Groundwater Depletion from GRACE}

GRACE is a joint project between the National Aeronautics and Space Administration (NASA) of the United States and the German Aerospace Center (DLR) that was launched in March 2002 to map Earth's static and temporal global gravity fields [29]. The variability in Earth's gravity field is directly related to the spatiotemporal variations in the total vertically integrated terrestrial water storage [30]. The GRACE-derived TWS is used extensively in hydrology, oceanology, cryosphere, and solid Earth fields (e.g., [1, 31-36]).
In this study, solutions derived from GRACE, available from University of Texas Center for Space Research (UT-CSR), were used to quantify TWS. The CSR mascon solutions approach uses the geodesic grid technique [37] to model the surface of the Earth using an equal-area gridded representation of the Earth via 40,962 cells (40,950 hexagons +12 pentagons). The size of each cell is about equatorial $1^{\circ}$, the number of cells along the equator is 320, the average area of each cell is $12,400 \mathrm{~km}^{2}$, and the average distance between cell centers is $120 \mathrm{~km}$. These mascons do not suffer from over-sampling at the poles like an equiangular grid. No neighboring cells meet at a single point [37]. The change in GWS is determined using the following equation: 
$\Delta \mathrm{GWS}=\Delta \mathrm{TWS}-\Delta \mathrm{SMS}$

$\Delta \mathrm{GWS}$ and $\triangle \mathrm{SMS}$ represent the change in groundwater and soil moisture storage, respectively. Four versions of the Global Land Data Assimilation System (GLDAS) [38-40] and the Community Land Model [41] were used to extract the soil moisture. The GLDAS model provides reasonable estimates of soil moisture over the arid environment of North Africa and the Middle East [32]. It is a land surface modeling system developed by NASA that incorporates fieldand satellite-based observations to derive detailed advanced simulations of climatic and hydrologic variables [42]. The GLDAS model simulates TWSgldas (a summation of soil moisture, snow, and canopy storage) through the four model versions mentioned above. The four GLDAS versions mentioned were used in this study after subtraction of the temporal mean (from April 2002 to April 2016) from each version. Given the fact that the study area is in a hyperarid region with minimal vegetation and no surface water reservoirs, the GLDAS-derived snow and canopy storages were neglected. The mean soil moisture estimates of the four TWSgldas simulations were calculated and then subtracted from TWSgrace estimates to quantify the GWSgrace variability over the investigation area.

The trend error in $\sigma_{\text {GWS }}$ was calculated using standard error propagation equation:

$\sigma \mathrm{GWS}=\sqrt{\left(\sigma_{\mathrm{TWS}}\right)^{2}}+\sqrt{(\sigma \mathrm{SM})^{2}}$

where $\left(\sigma_{\mathrm{SM}}\right)$ is the error of soil moisture that calculated from standard deviation of the trends that were computed from the four GLDAS simulations, and ( $\sigma_{\text {TWS }}$ ) is the error of terrestrial water storage that were calculated using procedures described in Scanlon et al. [43].

\subsection{Ionic Composition of Cations and Anions of Groundwater Samples}

All the water samples were stored in 1-L polyethylene bottles that were kept between 1 and $5^{\circ} \mathrm{C}$. The water samples taken for trace-element analyses were collected using sterile 100$\mathrm{mL}$ plastic bottle designed for bacteriological examinations. Hydrogen ion concentration $(\mathrm{pH})$ and electrical conductivity (EC) were determined at the sampling sites by using a portable $\mathrm{pH}$ meter and $\mathrm{EC}$ meter after calibration by using Thermo Fisher Scientific Instruments (Massachusetts, USA). Ionic composition (cation and anion) and trace elements have been determined by several methods; see Table 1 .

\subsection{Radioactive Analysis}

Radioactive materials were used to measure gross $\alpha$ and gross $\beta$ activities. Following the method of Salonen [44] and
Table 1 Analytical methods

\begin{tabular}{lll}
\hline Measurement & Method & Quantification \\
\hline $\mathrm{Ca}, \mathrm{Mg}$ & Flam atomic absorption & $0.1 \mathrm{mg} / \mathrm{l}$ \\
$\mathrm{Na}, \mathrm{K}$ & Flam photometry & $0.1 \mathrm{mg} / \mathrm{l}$ \\
$\mathrm{HCO}_{3}$ & $\begin{array}{l}\text { Acid titration with colored } \\
\text { indicator }\end{array}$ & $0.1 \mathrm{mg} / \mathrm{l}$ \\
$\mathrm{Cl}$ & Specific electrode & $0.05 \mathrm{mg} / \mathrm{l}$ \\
$\mathrm{SO}_{4}$ & Nephelometry & $0.05 \mathrm{mg} / \mathrm{l}$ \\
$\mathrm{NO}_{3}$ & Colorimetry & $0.05 \mathrm{mg} / \mathrm{l}$ \\
$\mathrm{Trace}_{3}$ elements & Furnace atomic absorption & $0.1-1 \mu \mathrm{g} / \mathrm{l}$ \\
\hline
\end{tabular}

Sanchez-Cabeza et al. [45-47], an aliquot of the water sample (about $60 \mathrm{~mL}$ ) was filtered using a $0.45-\mu \mathrm{m}$ membrane filter and then warmed on a hot plate stirrer for $1 \mathrm{~h}$ at about $60{ }^{\circ} \mathrm{C}$, while being stirred in a narrow neck conical flask to remove radon. The sample was cooled to room temperature, and any change in volume due to evaporation was corrected by adding a few drops of distilled water. Gross $\alpha$ and gross $\beta$ determinations were performed by direct measurement of $8 \mathrm{~mL}$ of the $\mathrm{Rn}$-free sample and $12 \mathrm{~mL}$ of liquid scintillation cocktail in a $20-\mathrm{mL}$ polyethylene vial for $500 \mathrm{~min}$. The sample was vigorously shaken and cooled for $3 \mathrm{~h}$, and then, counting began with a liquid scintillation spectrometer using a pulse shape analyzer for $\alpha / \beta$ discrimination. Immediate counting reduces Rn ingrowth interference to a minimum. Two control samples (blank and standard samples) were prepared and measured as unknown samples. The blank sample was deionized water, whereas the standard was a standard solution composed of a mixture of ${ }^{241} \mathrm{Am}$ and ${ }^{90} \mathrm{Sr}$, in equilibrium with its daughter ${ }^{90} \mathrm{Y}$, in deionized water. The obtained results are compared to WHO standards and guidance levels to show a preliminary assessment of the radiological risk attached to groundwater use of these resources.

\section{Results}

\subsection{GWS from GRACE}

The observed GRACE-derived TWS depletion over the study area is related to variations in both soil moisture storage and GWS, since GRACE has no vertical resolution [48]. To quantify the GRACE-derived GWS variations over the Saq aquifer system, the GLDAS-derived soil moisture estimates are subtracted from the GRACE-derived TWS averaged from the UT-CSR mascons as shown in Eq. (1). Figure 2 shows the temporal variations in the GRACE-derived groundwater estimates over the Saq aquifer, revealing an average groundwater depletion rate of $-2.11 \pm 0.13 \mathrm{~km}^{3} / \mathrm{yr}$ for the region (e.g., [48]). Water-level data from Saq aquifer has been used to directly validate the GWS from GRACE depletion over Fig. 2. 


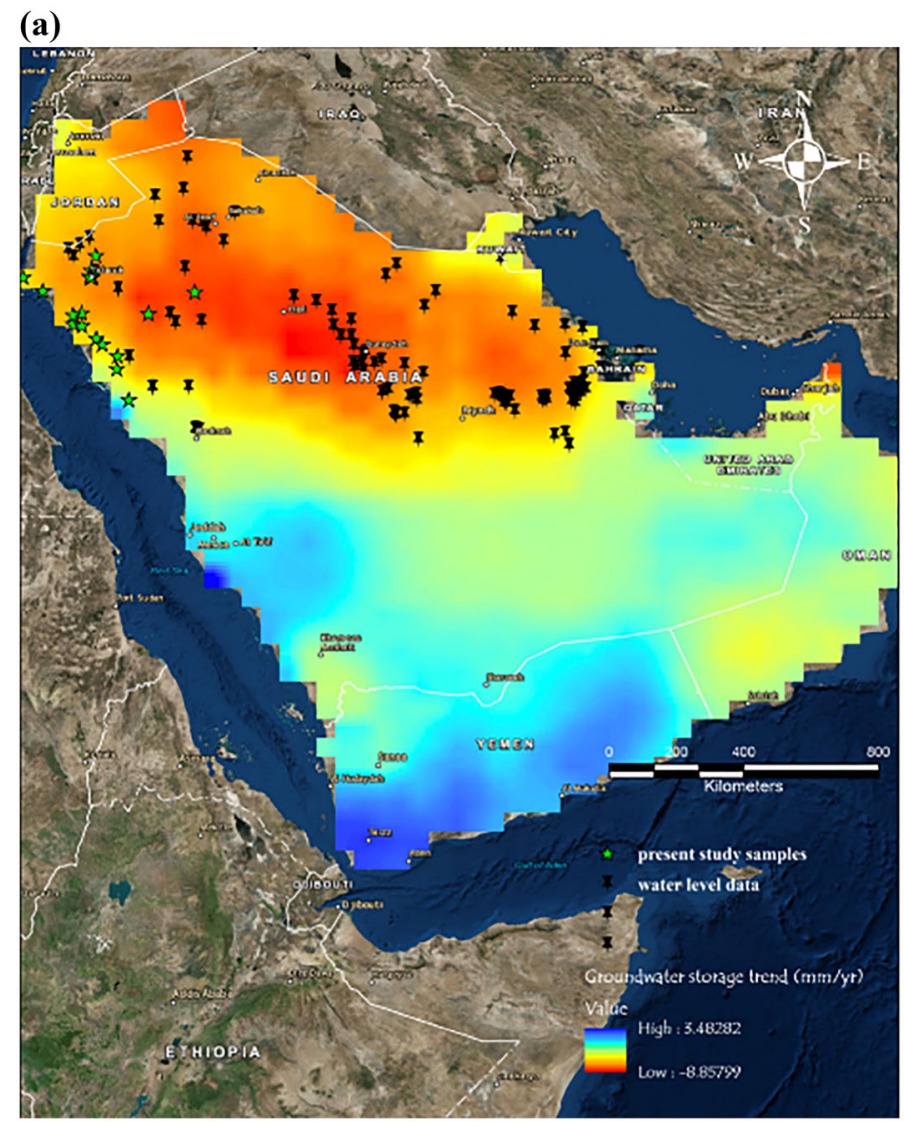

(b)

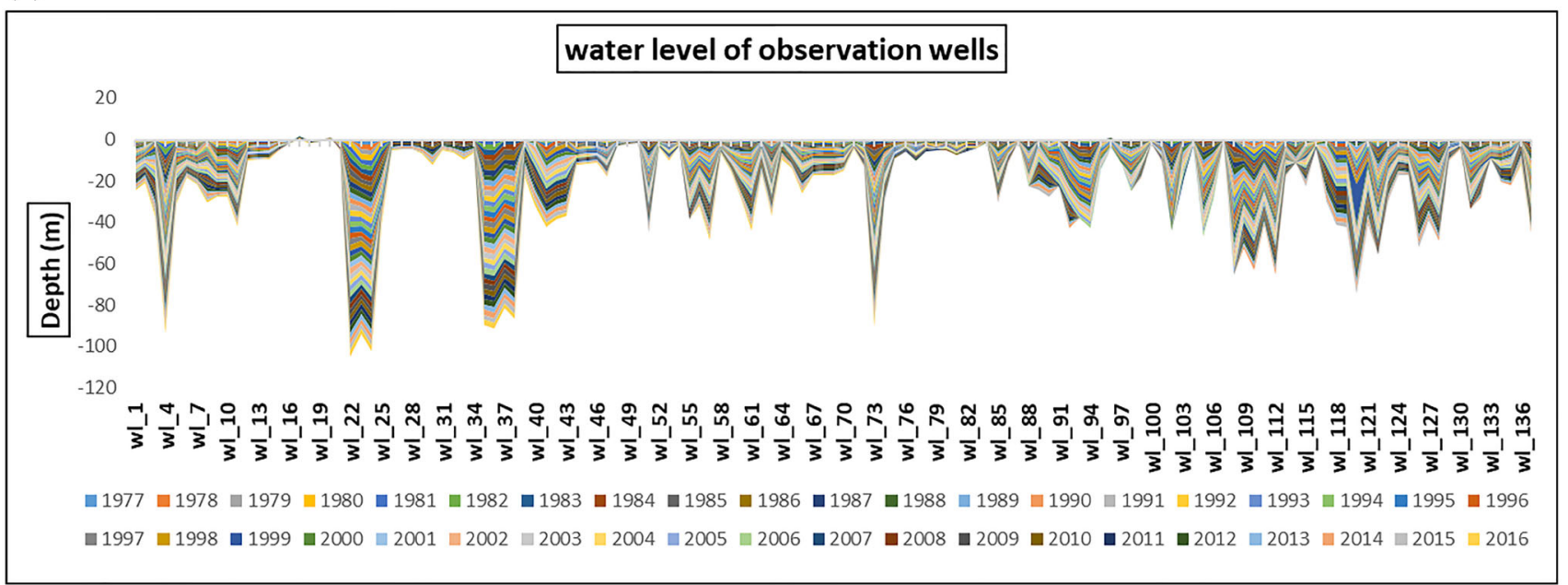

Fig. 2 a Secular trend in GRACE-derived groundwater storage estimates (in mm/yr) generated over the Arabian Peninsula from April 2002-2016, and distribution of groundwater observation wells (black

\subsection{Ionic Composition of Arabian Shelf and Arabian Shield}

Table 2 shows the results of the ionic composition in Arabian Shelf and Arabian Shield. The water samples are some- symbols; green stars for the present study) over the Arabian Peninsula. b Water level in meters of observation wells located on the map from 1977-2016

what acidic to neutral, with $\mathrm{pH}$ values ranging from 6.40 to 7.80 in the Arabian Shelf and from 7.10 to 8 in the Arabian Shield. (EC ranges from 460 to $1100 \mu \mathrm{S} / \mathrm{cm}$, with an average of $766.64 \mu \mathrm{S} / \mathrm{cm}$ in Arabian Shelf.) However, 95\% of the samples are over the maximum permissible limit of 
EC $(1500 \mu \mathrm{S} / \mathrm{cm})$ in the Arabian Shield. The total dissolved solids (TDSs) were measured by summing up all major ions' concentrations, which range from 253 to $660 \mathrm{mg} / \mathrm{L}$ in the Arabian Shelf with an average value of $479.92 \mathrm{mg} / \mathrm{L}$. Only $20 \%$ of the samples have TDS values $<500 \mathrm{mg} / \mathrm{L}$, which is below the $1200 \mathrm{mg} / \mathrm{L}$ standard from $\mathrm{WHO}$ and the $1000 \mathrm{mg} / \mathrm{L}$ standard of SASO $\mathrm{mg} / \mathrm{L}$. The water samples from the Arabian Shield have high TDS, with a maximum of $5417.5 \mathrm{mg} / \mathrm{L}$ and a minimum of $942.7 \mathrm{mg} / \mathrm{L} ; \sim 95 \%$ of these samples exceed the limit for water use. These high TDS values are probably linked to a local source of contamination of the aquifer, such as inadequate well protection and subsequent pollution from the soil surface into the well in question through non-cemented or poorly cemented annular spaces (MWA 2012). TDS distribution shows that the highest values, from 1200 to $5000 \mathrm{mg} / \mathrm{L}$, are observed in areas where the geological formations contain aquifer outcrops. The TDS in deeper groundwater samples is generally below $1200 \mathrm{mg} / \mathrm{LL}$, and in some places less than $500 \mathrm{mg} / \mathrm{LL}$ (MWA 2012)

Investigation focused on cation and anion distributions of sodium $\left(\mathrm{Na}^{+}\right)$, calcium $\left(\mathrm{Ca}^{++}\right)$, magnesium $\left(\mathrm{Mg}^{++}\right)$, potassium $\left(\mathrm{K}^{+}\right)$, chloride $\left(\mathrm{Cl}^{-}\right)$, sulfate $\left(\mathrm{SO}_{4}^{-2}\right)$, bicarbonate $\left(\mathrm{HCO}_{3}{ }^{-}\right)$, and nitrate $\left(\mathrm{NO}_{3}{ }^{-}\right)$, respectively. Table 2 shows that most of the cations and anions in the Arabian Shield exceed the standard of WHO and SASO due to several factors that affect the water quality in the region, such as high evaporation and high abstraction. The latter necessarily affects the gradients of the aquifer, driven both by residential and by industrial activities. The ionic compositions of Arabian Shelf waters are within the standards of the WHO and SASO, but the radioactivity (in terms of gross alpha and beta) exceeds the WHO guidance level.

\subsection{Hydrochemical Classification}

The classification of groundwater analysis was done using Piper's diagram [49], which is the best method to characterize the water quality and the relative contents of the major ions that determine the type of the water in the study area. From Piper diagram, the phenomena of TDS versus depth by the climatic variations during the course of the last several thousand years can be explained. Along the limit of the basement outcrop, the groundwater corresponds to water that has infiltrated under increasingly arid conditions. Such conditions have favored the evaporation of runoff and the deposition of salty deposits in the soils, such as duricrust, leading to an increase in the salinity of the water infiltrated down into the aquifer. Farther from the basement outcrop, in the confined parts of the aquifer that are preserved from present runoff infiltration, it can be assumed that the corresponding water has infiltrated under more temperate conditions characterized by a lower mineral enrichment during infiltration [8]. The ternary diagrams (Fig. 3) show three types of groundwater identified in this study. Type I occurs in the confined section near the outcrops all over the study area. Type II occurs in the basaltic area, in the confined section in the northeast of the study area. Type $\amalg$ occurs in the outcrops and shallow wells in the western part of the study area and in some deep wells near the outcrops in the eastern part.

Most of the samples fall in groups I and II, which show evolved $\left(\mathrm{Ca}^{2+}-\mathrm{Cl}^{-}\right)$and mixed $\left(\mathrm{Ca}^{2+}-\mathrm{Mg}^{2+}-\mathrm{Cl}^{-}-\mathrm{SO}_{4}{ }^{2-}\right)$ types, where unique chemical masking is achieved through rock-water interactions (ion exchange, reverse ion exchange, reactions within unsaturated zones, and increased residence time) and anthropogenic influences. The group III water type $\left(\mathrm{Ca}^{2+}-\mathrm{HCO}_{3}{ }^{-}\right)$represents meteoric signatures or fresh recharged water and constitutes only $5 \%$ of the total samples.

\subsection{Radioactivity Analytical Results}

We also performed radiological analysis of the Saq aquifer system and adjoining waters to investigate links with groundwater patterns and radioactivity. Twelve well samples were taken from basement granite and related alluvium, including those at the interface of granite and alluvium. An additional 12 well samples were taken from the unconfined sector of the Saq aquifer. Most of the samples obtained from Saq aquifer area have a high value of gross $\alpha$ and gross $\beta$, exceeding the WHO limit (Table 2). The main rock types and the sources of high radioactivity are basement rock, sandstone characterizing the Saq aquifer, and shale in the Hanadir Member of the Qasim Formation. The basement is located below the Saq aquifer and laterally limits its extension westwards. The Saq aquifer is overlain by Hanadir shale. The radiological activity of the different rock types seen here is summarized in the literature [50-54] as follows:

- Granite basement exhibits an average content of $3 \mathrm{mg} / \mathrm{kg}$ of uranium: $1-190 \mathrm{~Bq} / \mathrm{kg}$ of radium $\left({ }^{226} \mathrm{Ra}\right)$.

- Sandstone is not known for its high radionuclide concentration; it shows about $1 \mathrm{mg} / \mathrm{kg}$ of uranium and activity of less than $60 \mathrm{~Bq} / \mathrm{kg}$ of ${ }^{226} \mathrm{Ra}$.

- Shale with an average content of $3.7 \mathrm{mg} / \mathrm{kg}$ of uranium has $10-2300 \mathrm{~Bq} / \mathrm{kg}$ of ${ }^{226} \mathrm{Ra}$. Therefore, the origin of radioactivity in the Saq aquifer water seems more likely related to leakage of radioactive materials from adjacent layers into the Saq, rather than being intrinsic to Saq waters. 


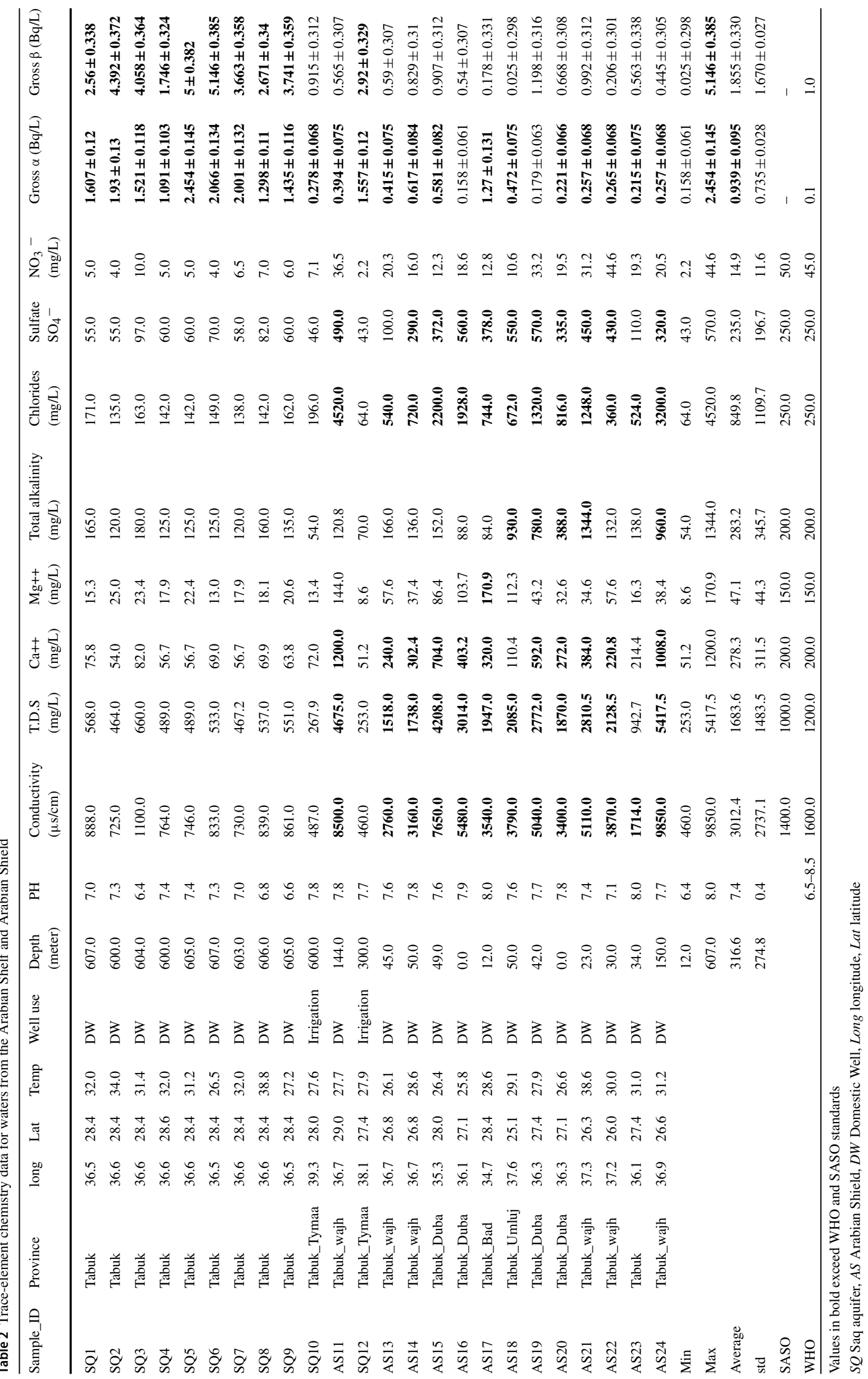




\section{EXPLANATION}

- SQ1

- SQ2

- SQ3

SQ4

A SQ5

$\triangle$ SQ6

$\nabla \mathrm{SQ} 7$

- SQS

* SQ9

+ SQ10

$\times$ SQ11

A SQ12

- SQ13

- SQ14

- SQ15

ㄴ. SQ16

- SQ17

$\triangle$ SQ1S

$\checkmark$ SQ19

$\nabla \quad$ SQ20

* SQ21

$+\mathrm{SQ} 22$

$\times \quad$ SQ23

- SQ24
Piper diagram: general overview of Saq and Arabian Shield water quality

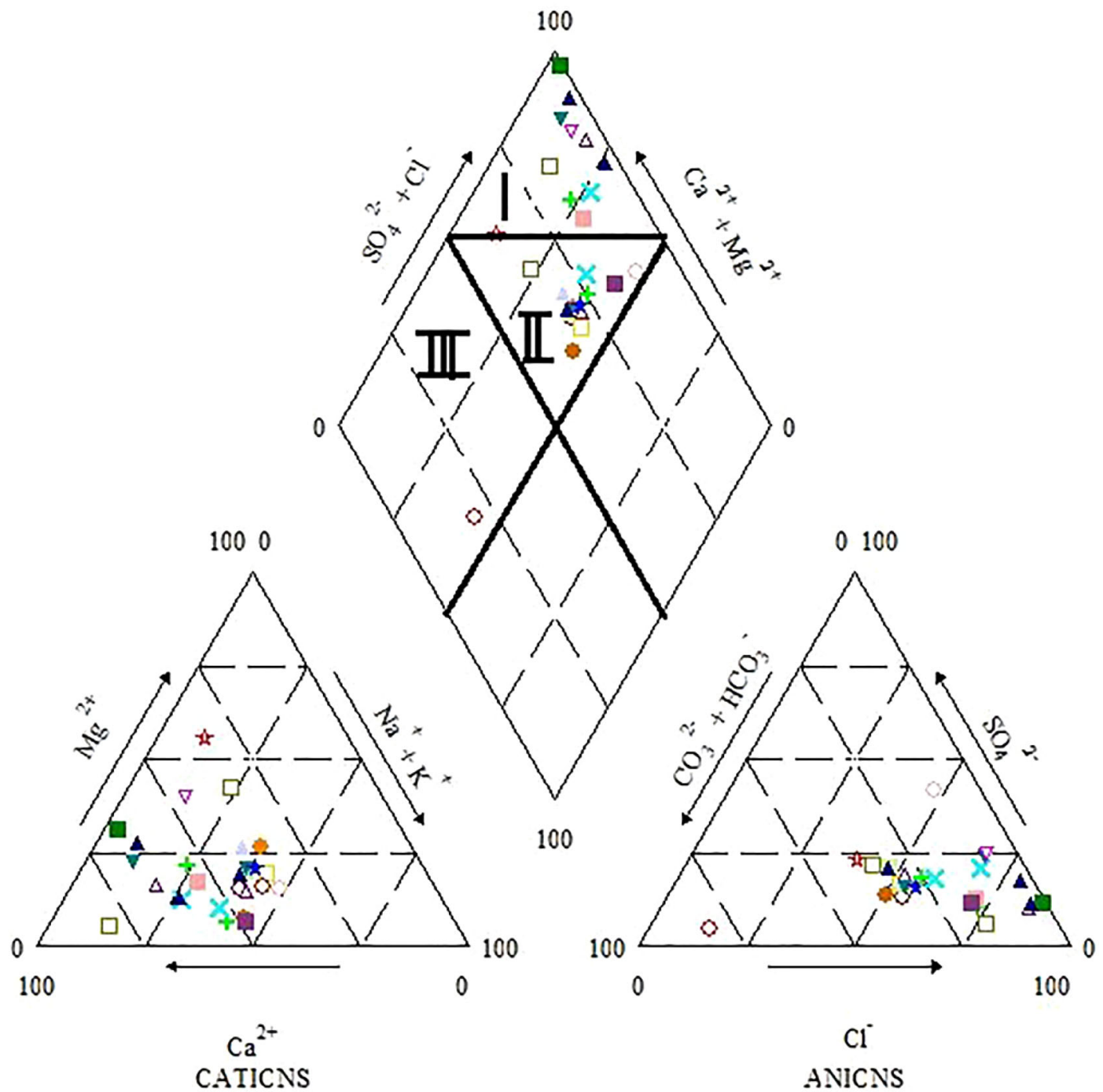

Fig. 3 Piper diagram of water samples from the Arabian Shelf and Arabian Shield

\section{Discussion and Conclusion}

This study focused on examining water quality in two regions of Saudi Arabia with distinctly different geological characteristics. Most of the samples were collected from the Arabian Shield, from wells used for domestic and drinking purposes, situated on coastal aquifers on the Red Sea coast; these waters show very high TDS, above the limit recommended globally and locally. According to the WHO and SASO, this water is not suitable for drinking, but can be used for other purposes. The high salinity of this water is likely related to saltwater encroachment in coastal aquifers, where pumping reverses original hydraulic gradients and results in increased total dissolved mineral concentrations. On the other hand, TDS distribution is influenced by various fac- tors. For example, the geological formations corresponding to the aquifer are the exposed situation, which leads to a decrease in TDS versus depth. Such a trend is not common, as groundwater enrichment in dissolved elements is generally linked to the length of the underground flow. The low TDS of the deep confined parts of aquifers (i.e., the samples in the Arabian Shelf) is related to groundwater recharge that took place under more humid climatic conditions in the past [2]. In addition, the proximity of wadis subject to occasional floods and surface water collection areas are reflected by high TDS values in adjacent unconfined aquifers. Because of this, most of the cations and anions in the Arabian Shield samples have a concentration higher than the standard limit for drinking water. A Piper diagram clearly illustrates the dramatic differences in water quality; most of the water sam- 
ples were related to a $\mathrm{Ca}^{2+}-\mathrm{Cl}^{-}$-type water and a mixed-ion $\mathrm{Ca}^{2+}-\mathrm{Mg}^{2+}-\mathrm{Cl}^{-}-\mathrm{SO}_{4}{ }^{2-}$-type water, the second of which appears to be sourced from the confined aquifer near the outcrops of the study area. The third distinct water (Type III) is a $\mathrm{Ca}^{2+}-\mathrm{HCO}_{3}{ }^{-}$water, representing a recharged, meteoricderived water. The results of the radioactive analysis in this region were found to be average and are within the standard limits for drinking water. The samples collected from the Arabian Shelf have ionic compositions within the standard limits for drinking water. The majority of samples from the Arabian Shelf fall in the mixed $\mathrm{Ca}^{2+}-\mathrm{Mg}^{2+}-\mathrm{Cl}^{-}-\mathrm{SO}_{4}{ }^{2-}$ type and show an evolved groundwater type that is related to the different periods of climate conditions. Our investigation in this region using radioactive analysis revealed that most of the samples from the Saq aquifer area have a high value of gross $\alpha$ and gross $\beta$ exceeding the WHO limit. However, according to the WHO, there is no health concern for using this water from both regions in the short term.

Water is a valuable resource in the Arabian Peninsula's current hyperarid conditions. In the KSA, for example, there are no surface rivers, lakes, or reservoirs. To sustain its growing population, KSA currently depends heavily on its groundwater resources and is planning to increase its rates of groundwater extraction in the near future. The lack of an understanding of the available groundwater resources, the spatiotemporal depletion rates, and the locations of extraction pose enormous challenges to the future of KSA.

This study included an integrated, cost-effective approach that combines state-of-the-art GRACE data and GIS techniques along with other relevant land surface models, remote sensing, geological, and hydrological data to examine the spatiotemporal variations in the groundwater resources of the Saq aquifer system and to explore the natural and anthropogenic drivers of these variations. The results of this study will contribute to the effective and efficient utilization of the water resources of the Saq aquifer and will be used to promote the sustainable development of the Arabian Peninsula's natural resources in general. The study findings are being shared with decision makers in relevant governmental agencies with the aim of developing sustainable management scenarios for the Saq aquifer.

Acknowledgements The author would like to sincerely thank the Ministry of Water and Environment, Tabuk Branch, for their help with analyzing the water quality of the samples that were used in this project. The author also wishes to thanks King Abdulaziz University department of Nuclear Engineering (Dr. E.I. Shabana, M. Qutub, and M. Tayeb) for their help and advices on radiochemical analysis. Finally, he wishes to thank Dr. Dawn Cardace and Dr. Ali Akanda for their kind help in finalizing this work and submitting it to this journal.

Open Access This article is distributed under the terms of the Creative Commons Attribution 4.0 International License (http://creativecomm ons.org/licenses/by/4.0/), which permits unrestricted use, distribution, and reproduction in any medium, provided you give appropriate credit to the original author(s) and the source, provide a link to the Creative Commons license, and indicate if changes were made.

\section{References}

1. Ahmed, M.; Sultan, M.; Wahr, J.; Yan, E.: The use of GRACE data to monitor natural and anthropogenic induced variations in water availability across Africa. Earth Sci. Rev. 136, 289-300 (2014). https://doi.org/10.1016/j.earscirev.2014.05.009

2. Sultan, M.; Ahmed, M.; Wahr, J.; Yan, E.; Emil, M. K.: Monitoring aquifer depletion from space: case studies from the Saharan and Arabian aquifers. In: Lakshmi, V. (ed.) AGU Geophysical Monograph \# 206. Remote Sensing of the Terrestrial Water Cycle, pp. 349-366 (2014)

3. Sultan, M.; Metwally, S.; Milewski, A.; Welton, B.: Modern recharge to fossil aquifers: geochemical, geophysical, and modeling constraints. J. Hydrol. 403, 14-24 (2011). https://doi.org/10. 1016/j.jhydrol.2011.03.036

4. GASTAT. General authority for statistics. Available at http://www. stats.gov.sa/en (2016). Accessed 24 Dec 2016

5. MEWA. Ministry of Environment, Water and Agriculture. Available at: http://www.mowe.gov.sa/enindex.aspx? AspxAutoDetectCookieSupport=1 (2016). Accessed 25 Dec 2016

6. FAO/WHO Expert Committee on Food Additives. Food and Agriculture Organization \& World Health Organization. (2006). Safety evaluation of certain food additives (No. 56). World Health Organization.

7. Al-Sayari, S.S.; Zoetl, J.G. (eds.): Quaternary period in Saudi Arabia. In: 1: Sedimentological, hydrogeological, hydrochemical, geomorphological, and climatological investigations in Central and Eastern Saudi Arabia, Springer, Wien (1978)

8. BRGM: Water, Agriculture and Soil Studies of Saq and Overlying Aquifers. Ministry of Agriculture and Water, Kingdom of Saudi Arabia (1985)

9. Edgell, H.J.: Geological framework of Saudi Arabia—groundwater resources. KAU J. Earth Sci. 3, 267-285 (1987)

10. Hussein, M.T.; Bazuhair, A.G.; Ageeb, A.E.: Hydrogeology of the Saq Formation east of Hail, northern Saudi Arabia. Quar. J. Eng Geol. 25, 57-64 (1992)

11. Jerais, A.A.: Hydrogeology of Saq Aquifer in Hail Region. Earth Sciences, King Abdulaziz University, Jeddah (1986)

12. Lloyd, J.W.; Pirn, R.H.: The hydrogeology and groundwater resources development of the Cambro-Ordovician sandstone aquifer in Saudi Arabia and Jordan. J. Hydrol. 121, 1-20 (1990)

13. Ministry of Agriculture and Water (MAW): Water Atlas of Saudi Arabia. Riyadh, Saudi Arabia (1984)

14. Sowayan, A.M.; Allayla, R.: Origin of the saline groundwater in wadi Ar-Rimah, Saudi Arabia. Ground Water 27, 481-490 (1989)

15. Segar, D.A.: A groundwater model of the Saq and Tabuk sandstone aquifers in southeast Jordan and northwest Saudi Arabia. M.Sc. Thesis, School of Earth Sciences, University of Birmingham, UK (1988)

16. Al-Omran, A.M.; Mousa, M.A.; AlHarbi, M.M.; Nadeem, M.E.: Hydrogeochemical characterization and groundwater quality assessment in Al-Hasa, Saudi Arabia. Arab. J. Geosci. 11(4), 79 (2018)

17. Alizadeh, M.J.; Nodoushan, E.J.; Kalarestaghi, N.; Chau, K.W.: Toward multi-day-ahead forecasting of suspended sediment concentration using ensemble models. Environ. Sci. Pollut. Res. 24(36), 28017-28025 (2017)

18. Aly, A.; Alomran, A.; Alwabel, M.; Almahaini, A.; Alamari, M.: Hydrochemical and quality of water resources in Saudi Arabia groundwater: a comparative study of Riyadh and Al-Ahsa Regions. Proc. Int. Acad. Ecol. Environ. Sci. 3(1), 42 (2013) 
19. Nazzal, Y.; Ahmed, I.; Al-Arifi, N.S.; Ghrefat, H.; Zaidi, F.K.; El-Waheidi, M.M.; Zumlot, T.: A pragmatic approach to study the groundwater quality suitability for domestic and agricultural usage, Saq aquifer, northwest of Saudi Arabia. Environ. Monit. Assess. 186(8), 4655-4667 (2014)

20. Sharaf, M.A.; Hussein, M.T.: Groundwater quality in the Saq aquifer, Saudi Arabia. Hydrol. Sci. J. 41(5), 683-696 (1996)

21. Wang, W.C.; Xu, D.M.; Chau, K.W.; Lei, G.J.: Assessment of river water quality based on theory of variable fuzzy sets and fuzzy binary comparison method. Water Resour. Manag. 28(12), 4183-4200 (2014)

22. SASO-GSO-1863:2013 Food packages-part 2 plastic packages-general requirement.

23. Brown, G.F.: Geomorphology of Western and Central Saudi Arabia: International Geological Congress, 21st, Copenhagen, 1960, Proceedings, sec. 9, pp. 150-159 (1960)

24. Ministry of Petroleum and Mineral Resources (MPMR): Tectonic Map of the Arabian Peninsula: Saudi Arabian Deputy Ministry for Mineral Resources, Ministry of Petroleum and Mineral Resources, Arabian Peninsula Map AP-2, Scale (1972)

25. Schmidt, D.L.; Hadley, D.G.; Greenwood, W.R.; Gonzalez, L.; Coleman, R.G.; Brown, G.F.: Stratigraphy and Tectonism of the Southern Part of the Precambrian Shield of Saudi Arabia. U.S. Geological Survey, Saudi Arabian Project Report 139 (1972)

26. Greenwood, W.R.; Anderson, R.E.; Fleck, R.S.; Roberts R.S.: Precambrian Geologic History and Plate Tectonic Evolution of the Arabian Shield: U.S. Geological Survey, Saudi Arabian Project Report 222 (1977)

27. Brown, G.F.; Jackson, R.O.: (1978) An overview of the Geology of Western Arabia. U.S. Geological Survey, Saudi Arabian Project Report 250

28. MacDonald, M., et al.: Final Report V., Regional Geology and Geophysical Investigation. Ministry of Agriculture and Water, Riyadh, no. 18, pp. 70-73 (1975)

29. Tapley, B.D.; Bettadpur, S.; Watkins, M.; Reigber, C.: The gravity recovery and climate experiment: mission overview and early results. Geophys. Res. Lett. 31(9), 1-4 (2004). https://doi.org/10. 1029/2004GL019920

30. Wahr, J.; Molenaar, M.; Bryan, F.: Time variability of the Earth's gravity field: hydrological and oceanic effects and their possible detection using GRACE. J. Geophys. Res. 103(B12), 30205-30229 (1998)

31. Ahmed, M.; Sultan, M.; Wahr, J.; Yan, E.; Milewski, A.; Sauck, W.; Welton, B.: Integration of GRACE (Gravity Recovery and Climate Experiment) data with traditional data sets for a better understanding of the time-dependent water partitioning in African watersheds. Geology 39(5), 479-482 (2011). https://doi.org/10.1130/G31812.

32. Ahmed, M.; Sultan, M.; Yan, E.; Wahr, J.: Assessing and improving land surface model outputs over Africa using GRACE, field, and remote sensing data. Surv. Geophys. 37(3), 529-556 (2016). https://doi.org/10.1007/s10712-016-9360-8

33. Famiglietti, J.S.: The global groundwater crisis. Nat. Clim. Change 4(11), 945-948 (2014). https://doi.org/10.1038/nclimate2425

34. Famiglietti, J.S.; Rodell, M.: Water in the balance. Science 340, 1300-1301 (2013). https://doi.org/10.1126/science.1236460

35. Mohamed, A.; Sultan, M.; Ahmed, M.; Yan, E.; Ahmed, E.: Aquifer recharge, depletion, and connectivity: Inferences from GRACE, land surface models, geochemical, and geophysical data. GSA Bull. (2016). https://doi.org/10.1130/B31460.1

36. Wouters, B.; Bonin, J.A.; Chambers, D.P.; Riva, R.E.M.; Sasgen, I.; Wahr J.: GRACE, time-varying gravity. Earth Syst. Dyn. Clim. Change 77(11), 116801 (2014)

37. Save, H.; Bettadpur, S.; Tapley, B.D.: High-resolution CSR GRACE RL05 mascons. J. Geophys. Res. Solid Earth 121(10), 7547-7569 (2016)
38. Koren, V.; Schaake, J.; Mitchell, K.; Duan, Q.; Chen, F.; Baker, J.M.: A parameterization of snowpack and frozen ground intended for NCEP weather and climate models. J. Geophys. Res. 104, 19569-19585 (1999). https://doi.org/10.1029/1999JD900232

39. Koster, R.D.; Suarez, M.J.: Energy and water balance calculations in the Mosaic LSM. NASA Tech. Memo. 104606, 76 (1996)

40. Liang, X.; Lettenmaier, D.P.; Wood, E.F.: One-dimensional statistical dynamic representation of subgrid spatial variability of precipitation in the two-layer variable infiltration capacity model. J. Geophys. Res. 101(D16), 21403 (1996). https://doi.org/10.1029/ 96JD01448

41. Dai, Y.; Zeng, X.; Dickinson, R.E.; Baker, I.; Bonan, G.B.; Bosilovich, M.G.; Yang, Z.; et al.: The common land model. Bull. Am. Meteorol. Soc. 84(8), 1013-1023 (2003). https://doi.org/10. 1175/BAMS-84-8-1013

42. Rodell, M.; Velicogna, I.; Famiglietti, J.S.: Satellite-based estimates of groundwater depletion in India. Nature 460(7258), 999-1002 (2009). https://doi.org/10.1038/nature08238

43. Scanlon, B.R.; Zhang, Z.; Save, H.; et al.: Global evaluation of new GRACE mascon products for hydrologic applications. Water Resour. Res. 52, 9412-9429 (2016)

44. Salonen, L. Simultaneous determination of gross alpha and beta in water by low level liquid scintillation counting. In: Second Karlsruhe International Conference on analytical Chemistry in Nuclear Technology, Karlsruhe, FRG (1989)

45. Sanchez-Cabeza, J.A., et al.: Optimization and calibration of a low-background liquid scintillation counter for the simultaneous determination of alpha and beta emitters in aqueous samples. In: Noakes, J.E.; Schonhofer, F.; Polach, H.A. (eds.) Liquid scintillation spectrometry. Radiocarbon, pp. 43-50 (1993)

46. Chalupnik, S.; Lebecka, J.: Determination of ${ }^{226} \mathrm{Ra},{ }^{228} \mathrm{Ra}$ and ${ }^{224} \mathrm{Ra}$ in water and aqueous solutions by liquid scintillation counting. In: Proceedings of liquid scintillation conference on radiocarbon, Vienna, pp. 397-403 (1993)

47. Schonhofer, F.; Pock, K.; Friedmann, H.: Radon surveys with charcoal and liquid scintillation counting. J. Radioanal. Nucl. Chem. 193, 337-346 (1995)

48. Fallatah, O.A.; Ahmed, M.; Save, H.; Akanda, A.S.: Quantifying temporal variations in water resources of a vulnerable Middle Eastern transboundary aquifer system. Hydrol. Process. 2017, 1-11 (2017). https://doi.org/10.1002/hyp.11285

49. Piper, A.M.: A graphical procedure in the geochemical interpretation of water analyses, transactions. Am. Geophys. Union 25, 914-928 (1944)

50. Alabdula'aly, A.I.: Occurrence of radon in the central region groundwater of Saudi Arabia. J. Environ. Radioact. 44(1), 85-95 (1999)

51. Aoudeh, S.M.; Al-Hajri, S.A.: (1994). Regional distribution and chronostratigraphy of the Qusaiba Member of the Qalibah Formation in the Nafud Basin, northwestern Saudi Arabia. In: Al- Husseini, M.I. (ed.) Geo'94, The Middle East Petroleum Geosciences. vol. 1, pp. 143-154. April 25-27, 1994, Bahrain. GulfPetrolLink, Bahrain

52. Iyengar, M.A.R.: The natural distribution of radium. Environ. Behav. Radium 1, 59-128 (1990)

53. Michel, J.: Relationship of radium and radon with geological formations. In: Richard C.C.; Rebers P.A. (eds.) Radon, Radium, and Uranium in Drinking water, pp. 83-95 (1990)

54. Molinari, J.; Snodgrass, W.J.: The chemistry and radiochemistry of radium and the other elements of the uranium natural decay series. In: The Environmental Behavior of Radium, vol. 1, pp. 11-56, IAEA (1990) 